What does the library have to do with it?

The success of Finnish education in PISA tests and the role of school and public libraries 


\title{
What does the library have to do with it? \\ The success of Finnish education in PISA tests and the role of school and public libraries
}

\author{
Elizabeth Greef \\ IASL Vice-President Advocacy and Promotion
}

26 Denison Rd

Lewisham NSW 2049

AUSTRALIA

What does the library have to do with it? PISA and the role of libraries

\begin{abstract}
A synthesis of qualitative research examining foundational reasons for Finnish success in PISA tests including the role of school and public libraries; based on interviews with more than forty Finnish practitioners and experts in universities, schools, government organisations, municipal departments of education, school and public libraries in four cities. Brief consideration is also given to the use of technology in Finnish schools and the new digital agenda commencing in 2016.
\end{abstract}

KEYWORDS

PISA; Finland; schools; libraries; education 
The education system of Finland has drawn significant attention since the notable performance of Finnish students in the PISA (Programme for International Student Assessment) tests, conducted triennially since the year 2000. The consistent stellar performance spanned all three areas of competency measured in 15 year-olds - reading, mathematical and scientific literacy - and was notable for the level of equity in educational achievement across all schools and the small tail of struggling students (Kupari, 2011). PISA focuses on higher order thinking, problem-solving, motivation and metacognition (OECD, 2010a). although Finland's position has dropped slightly, it is still very close to the top of OECD nations' achievement (Appendix 1). This paper examines foundational reasons for Finnish success in PISA and considers the shift to the digital school; the analysis is based on the author's research trip through Finland in 2011 and subsequent research, the purpose of which was to investigate what in the Finnish school system and culture makes students successful in PISA tests and also what role school and public libraries play in this success. Areas of research included basic aspects of schooling; teaching and learning; libraries, reading and inquiry; assessment; global education; employment; professional development; teacher training; school structure; curriculum; student support and other aspects (Appendix 2). This paper synthesizes aspects of the research relevant to the academic success of Finnish students. The study incorporated qualitative research through unstructured and semi-structured interviews with more than 40 experts and practitioners, and participant observations while visiting four universities, fourteen schools at all levels, two government organisations, three municipal departments of education and eight public libraries in four cities (Appendix 3). The resultant report (Greef, 2012) was shared with St Andrew's Cathedral School (which supported the study), other Australian schools and government education bodies.

Finland is a sparsely populated European country with a strong social welfare system and high level of education and technological advancement. Finland was assessed as the most democratic country in the world (WorldAudit.org, 2015) and ranked first in the Yale Environmental Performance Index 2016. Only in 1921 education became compulsory for children aged 7 to 13 (Simola, 2005, p.458). The economy was agrarian and forest-based until World War 2 but has become knowledge-driven in recent years (Dahlman, Routti \& YläAnttila, 2005).

The primary reasons for Finnish students' ongoing success in PISA tests, based on my research and reading, are the:

1. Ethos of Finnish education - cultural factors; guiding principles; strong literacy tradition

2. Post-reform Finnish education policy and system; quality learning spaces

3. Outstanding teachers and teacher education

4. Excellent public libraries in cooperation with schools

5. High profile of reading

6. Holistic care of students - health screening; nutrition; special needs support; welfare groups

7. National improvement programs

8. Innovation strategies

\section{Ethos of Finnish education}

The ethos of life, government and education in Finland is very stable; integral to this is trust in authorities, transparency and a sense of doing it together. Continuity due to a strong degree of consensus in the community and within government regarding education and reading allows schools to flourish without being subjected to the vagaries of party politics and changing agendas. Central tenets are belief in a free comprehensive and inclusive education system based on equal opportunity, low child poverty (under 4\%) (Ravitch, 2011), offering multiple pathways for further education with universities open to all (Aalto, 2011). 
Education is student-centred and holistic; "good teaching, balanced growth, safety of students and the joy of learning together" are of central importance (Kallio, 2011).

Finnish education reveals surprising paradoxes and guiding principles, "... that teachers can teach less and students will learn more; that schools can test less and students will learn better and that competitiveness in a knowledge-based economy comes with co-operation, which starts in the classroom" (Sahlberg cited in O'Brien, 2010). Ravitch (2011) compares the situation to the USA: "Our [US] guiding principles: Competition, accountability, and choice. Finland has this singular goal: to develop the humanity of each child... Their guiding principles: equity, creativity, and prosperity." Another central tenet was expressed by Uno Cygnaeus, father of the Finnish folk school: The school and its curriculum should develop the skills of the head (brain), heart and hand (Hirvenoja, 2011). Working with the hands is excellent for hand-eye coordination, development of fine motor skills and independence, and integral to Finnish education, (Frantsi, 2011).

Finland has a strong and egalitarian tradition of literacy and reading; it was compulsory for people to be literate before they could marry since at least the 1700s. In 1897 Tweedie wrote: "No one can be married in Finland unless he be able to read to the satisfaction of his spiritual adviser. This means that all Finland can read. Yet in Russia, nearby, only a quarter of the population know how to read, and far fewer can write..." (Tweedie, 1897, pp.352-354). Finland is also racially and culturally relatively homogenous with only $3 \%$ of the population being immigrants (Ruohomäki, 2011).

\section{Post-reform Finnish education policy and school system}

While an intentional education reform process has been implemented over the past forty years, it has been driven by Finnish social values and best practice and informed by research. Transparency and openness, the aim of providing opportunities for all, social trust especially in teachers, and the commitment to quality with little waste seem to be hallmarks of the Finnish system. In 1970 only $30 \%$ of students completed upper secondary education (OECDb, 2010, 129). The 1970s saw substantial whole-scale education reform leading to the current Finnish school system (Alava, n.d.; Sahlberg, 2006); in the 1990s new quality educational standards were introduced (Alava, n.d.). A strong systemic approach to innovation and effective support of research and development ensued (Dahlman, Routti \& Ylä-Anttila, 2005). The national curriculum is designed by the Finnish National Board of Education (FNBE) with input from the Finnish Institute of Educational Research (FIER) in Jyväskylä as the research arm and with expert group support (Kupari, 2011). There are three levels of curriculum: national, municipal and school level (Mäki, 2011). In August 2016 a new basic education curriculum will be released (Ruohomäki, 2011), incorporating the concepts of information literacy and reading skills under "broad-based competence" and "multiliteracy" (Valtakorpi, H. \& Haaga, A., 2016).

Educational accountability in Finland may appear minimal; there are no school comparisons, no league tables and no competition (Sahlberg, 2011). Schools' increasing freedom in the 1990s was linked to budget cuts due to economic collapse; school inspections were scrapped to save money. However, there are systems in place offering transparent oversight. "National curriculum frameworks require that the school curriculum must describe how the performance of each school is done." (Sahlberg, 2006, p.22); schools submit plans with learning strategies on WILMA (educational ICT platform) for checking by the FNBE. Plans are evaluated at the end of the year by teachers and put up for all to see. The only form of national quality assurance is sample-based national tests carried out by the FNBE triennially in voluntary samples, with the purpose of providing support in giving fair marks across the country (Kupari, 2011). Feedback from these and from class-based assessment provides "intelligent accountability" (Sahlberg, 2006, p.22). 
The Finnish education system is based around truly comprehensive schooling/peruskoulu from Grades 1 to 9. Schooling is entirely free including materials until at least Grade 9 and maintains a strong focus on the core business of teaching and learning with almost no streaming along ability levels and no external examinations until matriculation. School sizes are comparatively small, 200 to 700 students; every child is known (Frantsi, 2011). Class size legally can be 25-30 but schools try to keep this nearer 20 (Kupari, 2011). Since 2012 preschools have been integrated into the education system (Ruohomäki, 2011); one year is compulsory (Mäki, 2016). University-linked teacher training schools/normaalikoulu, operate as normal schools except that student teachers do practicums there; supervising teachers are paid nearly double (Lauttaanaho, 2011; Korkeamäki, R., 2011). In Grades 10 to 12 two options exist, an academic upper secondary/lukio or a vocational stream/ammattikoulu; about $50 \%$ of students go into each stream and many flexible pathways enable students to attend university. Substantial curriculum-guided formative assessment is carried out at the classroom level (OECD, 2010, p.127). The National Board of Examination holds matriculation exams three times a year, which may be staggered. Schools operate with tremendous efficiency and minimal support staff. Efficiency is evident in Oulu where the timetabling matrix and curriculum is the same for all senior academic high schools/lukio. Students have considerable choice over the timing and sequence of courses and WILMA enables smooth and efficient self-enrolment and subject selection (Aalto, 2011). Efficiency is achieved from my observations by schools having access to a centralised education system database, outsourcing, the level of autonomy and focusing on core business.

Finnish students have a somewhat different experience of school. They start school at the age of seven, receive little homework, wear no uniforms and call their teachers by their first names (Louhivuori, 2011; Alatalo, 2011). They do not choose their school but attend the closest (Saarivirta, 2011). Every child receives a hot free meal daily at school. They learn more languages. Research indicates that learning foreign languages has positive cognitive effects (Garza, 2016). Students can receive free music lessons. They learn compulsory practical handwork skills, life-skills (cooking and budgeting) and home skills (home care, care of children, washing and ironing) (Lauttaanaho, 2011; Fredrikson, 2011).

As a Nordic country, Finland is a welfare-state with strong political consensus on values of equality and human rights. The architecture of libraries and schools is seen as an expression of these values (Louhivuori, 2011). Quality of the learning spaces in design and finish is very high with beauty, cleanliness, durability and sustainability planning evident. I visited Kirkkojärvi School with a group of British architects and school designers and they were astonished at the quality. Schools are well-designed, well-ventilated but heated with dining halls, wet rooms, kitchens, laundries and woodcraft rooms with exceptional equipment. Light and flexibility of spaces are key considerations; for example, gyms convert to theatres and have rock-climbing walls and dance facilities. Some schools house a joint-use library or language school (Louhivuori, 2011). Staffrooms and classrooms are inviting spaces with a homely atmosphere and casual seating. Striking artworks are evident; it is compulsory to spend $1 \%$ of the budget of a new or renovated building on artworks. Schools have excellent recreational spaces with no fences around school properties. All schools conveyed a sense of calm and happy engagement.

\section{Outstanding teachers and teacher education}

Studies of Finnish PISA achievement always attribute success to the excellence of teachers. All teachers (except Kindergarten) must have a Master's degree (Korkeamäki, R-L, 2011; Kupari, 2011; Louhivuori, 2011; Saarivirta, 2011; Frantsi, 2011; Itäpuro, 2011). Teachers are independent, deeply trusted and not inspected even by the principal (Kupari, 2011; Saarivirta, 2011). They find teaching rewarding and have a lot of freedom in implementing the curriculum (Saarivirta, 2011; Frantsi, 2011; Kupari, 2011; Louhivuori, 2011). The required number of teaching days is 187 to 190 days per year (Frantsi, 2011). The teaching 
year is 38 weeks. According to Murtagh (2010; OECD, 2010b, p.126), "Teachers in Finland spend under 600 hours a year teaching compared to 1100 in the US..."

In my observations Finnish classrooms had a positive ambience with students working happily and independently with teacher oversight. Strong student-staff relationships were evident. Students' sense of responsibility and independence is fostered. Classrooms are active with students moving around more. Online textbook platforms were used with data projectors to facilitate class discussions. Document cameras were used for modelling complex problem-solving in consultation with students. Teachers used excellent questioning techniques to propel discussion and linked to prior learning. Use of games in primary classes to reinforce concepts seemed prevalent. O'Sullivan (2011) observed similar strategies. The Nordic Study conducted after PISA 2000 found that Finnish students were more persevering with less interesting texts and they worked to the end of a task, possibly work ethic or the Finnish quality sisu/dogged determination. A hypothesis was developed after the 2006 PISA tests that Finnish students have an attitude of "no item left behind" (Sulkunen, 2011).

Provision of a strong university-based education is necessary and Finnish universities provide excellent academic training (Saarivirta, 2011). The best way of ensuring strong teaching candidates is what happens in Finland, where top students go into teaching (Korkeamäki, R-L, 2011; Kupari, 2011); the top 10\% become doctors or teachers. "Teachers are the top of the cream of Finnish society" (Korkeamäki, R., 2011). There is very tough competition to get into teaching courses; at Oulu University, primary teacher education is the most popular choice with 1000 plus applicants of which only $5 \%$ are accepted and in some courses only the top 3\%; this popularity is hard to understand as salaries are not very high (Korkeamäki, R-L, 2011). Compatibility tests are conducted beforehand in the form of interviews; it is very demanding to get to the stage of being accepted. Teaching is also becoming a more feminised profession because girls do better (Pasanen, I, 2011; Louhivuori, 2011); a concern is the noticeable disconnect with boys (Korkeamäki, R-L, 2011).

Provisions for ongoing training in the form of mentoring, sharing best practice, professional development (PD) and the possibility to have "job alternation leave" (Ollila, 2011) are positive for maintaining teacher quality. Sharing best practice across schools is common in Finland in areas like special education, technology, teaching immigrants, school library and teaching literature (Louhivuori, 2011). Voluntary mentoring is available for newly qualified teachers; for teachers with limited experience, inservices on topics like special needs, dealing with parents, and managing homework, are offered (Mäki, 2011). Each municipality has a pedagogical resource centre attached to the municipal department of education and these provide inservices, elearning and curriculum support. In addition to mentoring, three days of professional development is allocated per teacher per year (Frantsi, 2011). PD is free for all teachers in the Oulu area and people sign in themselves (Mäki, 2011).

\section{Excellent public libraries in cooperation with schools}

Finland is known to have excellent public libraries in all areas and this is believed to have an effect on PISA scores (Wigell-Ryynänen, 2011). The central importance of libraries is determined by three underpinning factors: legislation (everyone has a right to high quality library services wherever they live); strategy; and support money (Wigell-Ryynänen, 2011). Municipalities are responsible for public libraries and supply $60 \%$ of the cost of total expenditure, the state $40 \%$. In 2010 the cost of delivering public library services was calculated at 56 euros per head of population (Ministry of Education and Culture, 2011). The National Library digital gateway has recently been completed, resulting in a joint catalogue for the whole country (Wigell-Ryynänen, 2011). Public and school libraries cooperate to provide information literacy and reading support for students. 
Libraries are a most beloved institution in Finland and are seen to promote reading, culture and social cohesion. They have a very attractive ambience and offer inspirational programs. Some of the innovations Finnish public libraries have adopted are central locations in large shopping centres; collections for multicultural clientele; employing the concept of the library as a "living room" to determine layout, furniture and facilities; sound-proof rooms for Xbox and films; enormous CD and sheet music collections; recording and digitising facilities; sound-insulated music practice rooms; engaging social workers to help meet needs in the community through the library; offering weekly visits from a laptop doctor; activities for teens like breakdance competitions and poetry slams; taking students for 2 weeks' work experience; a reading dog, Borje, who "listens without judging" (Alameri, 2011); exciting promotional events offering music, magicians, impro theatre, manga-drawing classes and comic book events; booktalks; media education for pre-schoolers; cooperation programs with schools, for example:

- Teaching $2^{\text {nd }}$ graders about the library, how to treat material, issuing a library card

- Teaching $4^{\text {th }}$ graders (age 10) how to search for material on databases

- Teaching $7^{\text {th }}$ graders about copyright and more databases.

The key to success is to listen to the user, the "patron at the centre" (Wigell-Ryynänen, 2011). The rate of borrowing across the population is high. In 2014 there were 756 public libraries in Finland and 142 bookmobiles with a total stock of 40 million resources. Total loans were nearly 91 million items (16.76 per capita); visits to public libraries over the year totaled 50 million (9.29 per capita); library internet services were used 40 million times (Libraries.fi: Statistics, n.d.). The 2009 PISA data showed that as long as students have access to a library it is not so important where it is. The FNBE has asked for evidence regarding the value of school libraries but it is hard to find (Sulkunen, 2011). There are inadequate statistics available (Wigell-Ryynänen, 2011).

School libraries tend to be small and not highly developed in Finland although this is changing rapidly, especially in Espoo and Oulu. Historically school libraries largely disappeared in the 1970s as the government pushed cooperation with public libraries (Lauttaanaho, 2011). The movement for school libraries was largely driven by principals with vision. Hannele Frantsi (2011) developed a program to enhance literature teaching (later the Reading Diploma), and through this realised the need for school libraries, which started in earnest in Espoo in 2001. Hannele Frantsi (2011) spearheaded the drive for this by coordinating school libraries and inservice training. In 2002 EU funding led to a bigger project in 15 schools; Marja Kallio (2011) from Oulu visited Hannele Frantsi to gauge what was happening in Espoo. From 2002-2004 the "School Library of the Information Society" project operated in Oulu (Ojaranta, 2016). Since 2005 much has happened, including in Kuopio which has library teachers in all schools (Frantsi, 2011). A program "Wings for the School Library"/Koulukirjastotollesievet was developed; this included cataloguing, culling and library teachers being paid for 1-3 hours to run the library. Schools have small collections varying from 1,000 to 15,000 books (Frantsi, 2011). An honesty system for loans generally operates where students check out their own material. Teachers qualified in both teaching and librarianship are rare in Finland. A much higher level of service can be offered if there are qualified teacher librarians (Wigell-Ryynänen, 2011). For library teachers there is an 18month course linked with Turku University, accredited as an inservice offered through FNBE (not a library accreditation) (Frantsi, 2011). Now in building new schools or renovating old ones, school libraries are also built (Lauttaanaho, 2011).

In the Oulu region cooperation between libraries and schools is better than ever; the City of Oulu is committed to the continuous improvement and expansion of school libraries (Valtakorpi and Haaga, 2016; Kauppila, 2016). Eeva Kurttila-Matero's (2011) seven-year study of the school library as a tool for developing the school's operating culture may have influenced this trend. Another positive change is that schools, public libraries and cultural institutions now come under the same organization, Sivistys- ja kulttuuripalvelut, making planning and goal-setting easier (Kallio, 2016). Currently in the Oulu region there is a project, 
"Library Route"/Kirjastoreitti, of systematic cooperation with schools. This has been developing since the first "five-year plan" of 2008; the current one was developed after the amalgamation of four municipalities in 2013: Oulun koulukirjasto: Kehittämissuunnitelma 2014-2016 (Kallio, 2011, 2016). The main objective of Kirjastoreitti is for each student to visit the library at least four times during their schooling and to build their information literacy and reading skills (Kauppila, 2016). An information specialist coordinates the cooperation of 23 libraries and 80 comprehensive schools in the municipality. This role has led to improved communication and understanding between libraries and schools; libraries now have a better understanding of the national curriculum and schools are aware of the services and resources available to them via Kirjastoreitti (Valtakorpi and Haaga, 2016). "Innovation Afternoons" are held for school library teachers. Development of the school library has been part of the curriculum since 2000 at Myllyoja School and is encapsulated in their Vision 2010 statement (Kallio, 2011). Ritarharju Multifunction Centre is an impressive school, one of twelve Microsoft Schools of the Future, with a joint-use library.

There are problems related to school libraries and their role. The Ministry of Education and Culture has delegated school libraries to the FNBE but with no accompanying structure money. There is acknowledgement within the Ministry, the FNBE and the municipalities that school library provision needs to be equal; however, this requires a system and development money would be needed to improve the situation (Wigell-Ryynänen, 2011).

There is substantial cooperation between public libraries and schools in programs focusing on reading, library protocols and information skills. The core curriculum requires the teaching of information literacy but teachers are not educated for this and there is no one in the school to fill this role (Frantsi, 2011). Library teachers have no time allocation to make an impact in this area. Public libraries try to fill the need for developing information literacy in students but it is not without its difficulties. Some issues have been mismatches in planning between libraries and schools (Fredrikson, 2011), inadequate computers for whole class instruction, the discomfort of library staff around young adults, limited time slots for school visits, expensive student travel costs, uneven voluntary take up of the opportunity (Kruuti, 2011), teaching skills out of context, the difficulty of finding a common language between teachers and librarians, and services end when the money runs out (Fredrikson, 2011). The KIRKOU project developed by Helsinki City Library between 2008 and 2011 offers teaching materials by grade, promotes familiarity with library services, information literacy and literature, and the development of school libraries (Fredrikson, 2011). While there has been some decline in Finland's overall PISA results, the most significant decline was in retrieving information and this needs to be investigated (Sulkunen, 2011). While libraries probably impact PISA results positively, this appears to be uneven; more impact has probably come from library reading support than information literacy interventions. Despite constraints, what public librarians and library teachers provide for students is impressive.

\section{High profile of reading}

Reading has a high profile and long tradition in Finland. Finnish language and literature are highly valued and Finns are among the best readers in the world. Nearly every home subscribes to a newspaper. The country is bilingual, Finnish-Swedish. Reading a lot is a foundational aspect of the success in PISA and is linked to lifelong learning; it also is a result of family tradition, a widespread recognition of the value of education and being part of a small language group where authors are held in high esteem (Wigell-Ryynänen, 2011). Television subtitles are also quite a motivator for the young to learn to read. Parents read the subtitles to their children too (Sulkunen, 2011). Subtitles may possibly help train fluency in decoding by providing cognitive resources for comprehension (Sulkunen, 2011).

Some trends and concerns in reading among Finnish students have been clearly noticed. Students can often read well at an early age. The Finnish language is highly phonetic and its orthography so transparent that $30-40 \%$ of children are able to crack the reading code 
themselves and can read before they go to school (Sulkunen, 2011). Dr Sari Sulkunen from FIER and PISA reading expert, emphasised how vital it is to develop an interest in reading in students and to help them develop effective reading strategies, particularly in summarising, understanding and memorising, together with a diversity of reading materials and online reading activity (Sulkunen, 2011). Students need skimming and scanning strategies even with print text. Schools also must get their students to engage critically with online texts (Sulkunen, 2011). We need to make explicit to students how important good literacy skills are and why, and that what you do and how often is very important (Sulkunen, 2011). Finnish girls are much better and more motivated readers than boys. The gender gap in reading is huge in Finland with boys showing less reading for leisure, less command of strategies and less diversity in reading (Sulkunen, 2011). An issue with boys is that reading is not seen to be cool due to both peer pressure and interests. Dr Pasi Sahlberg (2011) sees this as a critical aspect to be addressed; one idea was to mobilise grandparents to help children improve their reading.

Reading ability and engagement of students in reading is a widespread concern although student engagement and interest is strong in Finland (Välijärvi et al, 2003, p.17) especially among

girls. Brozo, Shiel and Topping (2008) conducted an analysis of reading engagement in three countries and noted:

"Engagement has been found to be a critical variable in reading achievement... Guthrie and Wigfield (2000)... noted that: 'As students become engaged readers, they provide themselves with self-generated learning opportunities that are equivalent to several years of education. Engagement in reading may substantially compensate for low family income and poor educational background...' the authors recommended that students increase the time allocated to personalised reading and that "a system of accounting for reading should be used."

In addition students should be encouraged to engage with a diversity of texts and text-types (Brozo, Shiel \& Topping, 2008, pp.307,311-312).

The success of reading and literacy programs in promoting a love of reading and creating engagement has been solidified through the national take-up by school and public libraries of the Reading Diploma program based on Literature Circles, widespread positive support and excellent websites. The Reading Diploma/Lukudiplomi (initially Netlibris; now Kunnari; "Reading to take flight"/Lukemalla lentoon in Jyväskylä and Joy of reading/Lukuinto in Oulu) was initially set up by Hannele Frantsi. The FNBE gave money to develop it further. Cooperation seminars are held with public library staff and library teachers to share ideas, communicate and plan. Public libraries take pains to support these programs fully by providing a diversity of learning materials, producing reading lists, creating displays, buying multiples of bestselling books, listening to what children want to read and limiting censorship (Wigell-Ryynänen, 2011). Students need to read 12 books signed off by the teacher, keep a reading log/kontolliste and can become a master or supermaster;. The enthusiasm for and level of ownership of the Reading Diploma program was very evident among teachers, librarians and students. Inservices are held through municipal education centres for teachers on how to get children to read and offer strategies on how to make literature alive. The supporting websites, like Kunnari offer competitions, logs and prizes as components of the program and online reading activities. There are also instructions on the library intranet for ways to teach certain skills and strategies (Kruuti, 2011). The reading programs are reinvented regularly to keep them fresh and appealing; much of this work is done at a regional level. The Lukuinto/Joy of Reading program in Oulu has an excellent handbook and the website details stories from the pilot project of cooperation with schools and also pedagogical practice supporting multi-literacy.

Writing is taught as a skill integrated with reading. The process of writing is emphasised and the idea of "less is more" is subscribed to. Critical thinking within writing is seen as vital - 
seeing the purpose of writing, why a text is written and why it works, and understanding the features (Kannio, 2011). Sari Sulkunen (2011) pointed me towards recent research on the haptics of writing, indicating that the specific motor action of forming letters physically is intimately linked with perception and with shaping cognition and reading competency (Mangan and Velay, 2010).

\section{Holistic care of students}

Finland has excellent health care including annual compulsory health screening of children aged 1 to 5 . A contributing factor to PISA success is this early annual screening of young children, which results in many problems being picked up before school begins (Kannio, 2011).

Many Finns believe that the free hot lunches provided for all students support PISA success. Catering companies supplied by the municipality have provided these for more than 50 years; consequently, Finnish students have very good nutrition. The cost is aimed to be EUR 0.60 per child per day (Itäpuro, 2011) and there is a 5-week circulating menu. Mealtimes are staggered and kitchens are well-organised to allow students to get their meals and clear up.

Finland also provides effective support and systems so that each child is able to achieve their potential. The overarching task of the school is to support inclusion as much as possible; teachers legally cannot exclude (Kielinen, 2011). In Finland "special needs" is termed "intensified support"/tehostettu tuki (Mäki, 2011). There are three levels of support available to any child: general support; more effective support; and special needs education. $10 \%$ of students have learning or behavioural problems (Frantsi, 2011; Louhivuori, 2011) but only $2 \%$ of children are in special education institutions (Alava, 2005). Special education teachers support $30 \%$ of students during a year. Individual learning plans (ILPs) for students include an estimate of the need for special support/pedagoginen arvio, (Mäki, 2011); every school has to have plans to integrate students into the mainstream. No streaming is employed except that students with special learning needs will be in a smaller class of 6-8 with special education teachers. Professional help can be sourced if needed. (Frantsi, 2011; Louhivuori, 2011)

The total commitment of Finns and the education system to equality and inclusion leads to a strong multi-faceted support system for students with special needs. Schools with a pedagogical approach and training arm to help equip teachers exist, like Tervaväylä School in Oulu, a state-owned special school for high needs children with integrated psychological, technical, therapeutic and medical support (Korkeamäki, R-L, 2011); it is a model EU school in providing opportunities for inclusion, special education training, integrated education and health care (Hurtig, 2011) and one of eight national service centres for special education directly under the FNBE providing effective learning support. The aim at the school is to understand needs from a pedagogical point of view and its main task is to support and promote inclusion as much as possible. The school has a significant professional development role in north Finland. The initial training of teachers also equips them to provide intensified support when required. Student welfare groups in schools decide if students should come to Tervaväylä's Lohipato unit, which has outstanding facilities for mobilityimpaired students like tracks on the ceiling to lift students from wheelchairs, hydraulicoperated counters and therapy rooms; students may stay from 2 days to 2 years (Hurtig, 2011).

Every school has weekly student welfare group meetings/Opiskelijahuolto with a psychologist, school nurse and teachers present to discuss the welfare of specific students (Frantsi, 2011; Louhivuori, 2011), generally chaired by the principal. Referrals to the group can come from parents or students voluntarily. There is very strict privacy legislation; the student needs to give permission for their situation to be discussed and has to have trust in confidentiality. Discussion of cases can be hard because of restrictions caused by group 
members working under different legislation; overall legislation for student welfare in high schools would be better (Aalto, 2011). Typical issues discussed were school avoidance, bullying and teasing and strategies to support students (Alatalo, 2011).

\section{National Improvement Programs}

In evaluating PISA success, the role of strategic national improvement programs for reading, mathematics and science, implemented since the mid-1990s, cannot be underestimated. In 1995, an evaluation Does Basic Education Create Equality? indicated that reading skills were in decline among $8^{\text {th }}$ Grade students. Since then, educational administration has made the promotion of reading skills a priority and rectification strategies included The Project to Re-establish School Libraries, the Year of Reading Skills 1997 and Reading Finland, 20012004. Widespread support exists for regional reading improvement programs from newspaper, periodical and publishers' associations and library and teachers' organisations (FNBE, 2011a).

During the 1990s curriculum reform led to an emphasis on science, technology and innovation, and an emphasis on teaching students to think creatively and manage their own learning and the Finnish government undertook improvement strategies in the areas of science and mathematics. LUMA was

"a development programme of the National Board of Education for mathematics and science education for 1996-2002. The project is a part of the national joint action launched by the Ministry of Education for raising mathematical and scientific knowledge in Finland to the international level. In Finland, science subjects are considered to include Physics, Chemistry, Biology and Physical Geography" (FNBE, 2011b).

The intention was to increase interest and sustain improvement in mathematics and sciences among both male and female students, to include an environmental approach, to integrate mathematics and science subjects with each other and with applications, to create opportunities for all students and through all levels of schooling from preschool on, and to provide learning environments "to encourage all students to observe phenomena, to perform experiments, to apply their knowledge in real life situations in solving problems" (FNBE, 2011b). These intentional strategies have no doubt had a flow-on positive effect on Finnish PISA results.

\section{Innovation Strategies}

Innovation as a skill and means of improvement is valued and nurtured in Finland. Sahlberg (cited in Darling-Hammond, 2010, p.169) identifies the impetus to innovation and creativity in Finnish education: "Rapid emergence of innovation-driven businesses in the mid-1990s introduced creative problem-solving and innovative cross-curricular projects and teaching methods to schools". The PISA 2009 Executive Summary indicates: "Finnish schools work to cultivate in young people the dispositions and habits of mind often associated with innovators: creativity, flexibility, initiative, risk-taking and the ability to apply knowledge in novel situations" (OECD, 2010a, p.13). An innovation strategy through libraries occurs via the Ministry of Education and Culture's fund of 1.2 million euros for project money. Libraries submit proposals for special projects to provincial state governments; a group of nine experts discuss these together prior to a final decision. This project funding has fostered an abundance of good and innovative ideas resulting in better library services and schools. A Project Register is kept on the web (Wigell-Ryynänen, 2011).

\section{The digital agenda}

Finland is technologically developed and ICT is widely used within schools, homes and in educational and library administration. However, the level of integration of ICTs is very varied and is often a challenge for the older generation of teachers (Saarivirta, 2011). It appears that the impact of ICT on PISA results so far has not been substantial. The government is pursuing a new digital agenda among many other reforms (Finnish 
Government, n.d.) According to the recent report on digitalisation in comprehensive schools, it was determined that the amount of devices was insufficient and wireless connection in many schools required improving and $20 \%$ of teachers are challenged by ICT (YLE Uutiset, 2016). Regarding student use of ICT, it is currently minimal for educational purposes: "In the light of the forthcoming new national curriculum, programming is still very rarely included in the study modules in comprehensive schools, and media contents are seldom produced by students for educational purposes" (Finnish Government, 2016). The Action plan for the implementation of the key project and reforms defined in the Strategic Government Programme (Prime Minister's Office, 2016) outlines the Finnish government plan Digiloikka/digital leap - to invest 121 million euros over three years to develop digital skills in education through teacher training and investing in the digital learning environment. Oulu City Department of Education has a well-planned and long-term "Digi-strategy" for implementation of ICT in education and a matrix of ICT levels per grade (Mäki, 2016).

Digital and elearning services are provided through educational resource centres like OPPIS and eVarikko; for example, provision of distance learning for Farsi, Arabic, Somali and Russian language classes, the Mediareppu Project offering ICT innovation in preschools, video-conferencing facilities, website design for schools, teacher training in ICTs, a centralised cataloguing service for school libraries, lessons in netiquette/Netiketti and social media etiquette/Someketti, consortium purchasing of databases and other software for schools, and the VIRTA project streaming online classes in different small language groups to schools across the municipality (Itäpuro, 2011). In Oulu distance education has been delivered for many years to remote schools via video links.

Standard equipment in every classroom observed was a data projector, a document camera and at least one computer. Each school usually had one or two computer labs and laptops were available in specialist classrooms. Considerable choice of excellent textbooks exists with fierce competition between the three educational publishers in Finland; integrated online learning platforms provide exercises and learning materials for each subject area and year level (Frantsi, 2011; Louhivuori, 2011). Sensible, stable national and regional technology systems are highly efficient and minimise data entry for Finnish schools. WILMA enables online roll marking, communication with parents, course selection for students, and data entry by parents (Aalto, 2011; Itäpuro, 2011). All Grade 1 students receive an email account for their subsequent schooling. The new digital agenda will change the landscape of Finnish education rapidly.

\section{Recommendations based on research study}

- Make wise selection of staff - the critical factor

- Establish an environment of trust and equality in schools

- Improve the ambience of classrooms and learning spaces

- Strengthen reading across the school; help students develop reading strategies

- Continue to encourage handwriting

- Increase inquiry, innovation \& creative problem-solving in learning

- Consider offering opportunities for handicrafts and working with hands (makerspaces)

- Encourage the learning of languages

- Provide early intervention and strong student support

- Encourage perseverance in learning, perhaps with a growth mindset approach.

There are many sensible elements in Finnish educational provision and organisation, which could reward further investigation. The lessons we can take from Finnish success are that we need to be designing education around the national, cultural and citizenship values we want our students to develop, being informed by the research into learning and education, and using best practice. Ultimately the frontline critical mediator of education is 
the teacher and attracting top quality candidates to the teaching profession is the most significant prime factor for success. Although the Finnish education system is only more recently recognising the importance and value of school libraries, it has always recognised the central importance of libraries for promoting education and cultural values and sought to serve children. At this point digital technology does not appear to have had a profound effect on Finnish education but this will soon change. A number of the key recommendations resulting from this research study - strengthening reading across the school, promoting inquiry learning, establishing opportunities for working with the hands, provision of learning spaces with a positive ambience - coalesce in the school library, allowing teacher librarians to offer strong support in the academic success and personal wellbeing of their students. 


\section{REFERENCE LIST}

Alava, J. (2005). Finnish students' performance success in PISA - and some reasons behind it. Paper presented at Nordic Principals' Forum 2005. [PPT]

Alava, J. (n.d.). From nation building into future creation. Institute of Educational Leadership, University of Jyväskylä. [PPT]

Brozo, W.G., Shiel, G. \& Topping, K. (2008). Engagement in reading: Lessons learned from three PISA countries. Journal of Adolescent \& Adult Literacy, 51(4), 304-315. Retrieved from http://www.academia.edu/3129071/Engagement in reading Lessons learned from three PISA countries

Dahlman, C., Routti, J. \& Ylä-Anttila, P. (eds). (2005). Finland as a knowledge economy: Elements of success and lessons learned: Overview. Washington, DC: The World Bank.

Darling-Hammond, L. (2010). The flat world and education: How America's commitment to equity will determine our future. New York: Teachers College Press.

Finnish Government. (n.d.). Implementation of the Government Programme. Retrieved from http://valtioneuvosto.fi/en/implementation-of-the-government-programme

Finnish Government. (2016). Report on digitalisation in comprehensive schools. Retrieved from http://valtioneuvosto.fi/en/artikkeli/-lasset publisher/selvitys-perusopetuksendigitalisaatiosta-valmistunut? 101 INSTANCE 3wysILo1Z0ni groupld=10616

Finnish national Board of Education (FNBE). (2011a). Literacy in Finland. Retrieved from

http://www.oph.fi/english/sources of information/international assessments/pisa/literacy in finland

Finnish National Board of Education (FNBE). ( 2011b). The LUMA programme. Retrieved from http://www.oph.fi/english/sources of information/international assessments/pisa/education development projects/luma

Garza, F. (2016). Being bilingual rewires the fundamental structure of your brain. Quartz, 18 February. Retrieved from http://qz.com/618475/being-bilingual-rewires-the-fundamentalstructure-of-your-brain/

Greef, E. (2012). Exploring Finnish success in PISA: Report on PISA trip to Finland, September, 2011. [Unpublished manuscript]

Kirjastoreitti. (n.d.). Retrieved from http://www.ouka.fi/oulu/kirjastoreitti/in-english

KIRKOU. (2016). Retrieved from www.kirkou.fi

Kunnari. (n.d.) http://www11.edu.fi/kunnari/

Kurttila-Matero, Eeva. (2011). School library: A tool for developing the school's operating culture. (Doctoral dissertation). Retrieved from http://jultika.oulu.fi/files/isbn9789514297366.pdf

Libraries.fi: Statistics. (n.d.). Retrieved from

http://www.libraries.fi/en-GB/library-branch/basic-information-about-finnish-libraries/statistics/

Lukemalla lentoon. (n.d.). Retrieved_from_http://www3.jkl.fi/kirjasto/lukudiplomi/index.htm

Lukuinto. (n.d.). Retrieved from http://www.lukuinto.fi/joy-of-reading/guides.html

Ministry of Education and Culture. (2011). Quality recommendation for public libraries. Retrieved from http://www.minedu.fi/export/sites/default/OPM/Julkaisut/2011/liitteet/OKM35.pdf?lang=fi

Mangen, A., \& Velay, J.-L. (2010). Digitizing literacy: reflections on the haptics of writing. In M.H. Zadeh, (Ed.), Advances in Haptics (pp. 385-402). Vienna: IN-TECH web.

Murtagh, C. (2010). Interview: Pasi Sahlberg (Finnish lessons). Holyrood Magazine, 228. Retrieved from http://www.holyrood.com/articles/2010/02/11/finnish-lessons

O'Brien, S. (2010). 'Finnovations' include education system. Red Deer Advocate. Retrieved from http://www.albertalocalnews.com/reddeeradvocate/news/local/Finnovations include educati on system 84112902.html

OECD. (2010a). PISA 2009 executive summary. Retrieved from http://www.oecd.org/dataoecd/34/60/46619703.pdf

OECD. (2010b). Finland: Slow and steady reform for consistently high results. In Strong performers and successful reformers in education: Lessons from PISA for the United States, (pp. 117135). Retrieved from www.oecd.org/dataoecd/34/44/46581035.pdf

Ojaranta, A. (2016). Library as a space for learning: the Finnish experience. Retrieved from https://prezi.com/s5c06gotgrta/library-as-a-space-for-learning/ 
O'Sullivan, B. (2011, 29 September - 5 October). Lessons from the Finnish classroom. Helsinki Times, p. 2.

Oulun koulukirjasto: Kehittämissuunnitelma 2014-2016. (n.d.). Retrieved from http://www.ouka.fi/c/document library/get file?uuid=1d2a8c4a-4ab6-434b-b8ec4aeb0ad03f7d\&groupld=1958741

Prime Minister's Office, Finland. (2016). Action plan for the implementation of the key project and reforms defined in the Strategic Government Programme. Retrieved from http://valtioneuvosto.fi/documents/10616/1986338/Action+plan+for+the+implementation+Str ategic+Government+Programme+EN.pdf/12f723ba-6f6b-4e6c-a636-4ad4175d7c4e

Ravitch, D. (2011). What can we learn from Finland? Retrieved from http://blogs.edweek.org/edweek/BridgingDifferences/2011/10/what can we learn from finl and.html

Sahlberg, P. (2006). Raising the bar: How Finland responds to the twin challenge of secondary education? Profesorado. Revista de curriculum y formacion del profesorado, 10(1). Retrieved from https://www.ugr.es/ recfpro/rev101ART4ing.pdf

Simola, H. (2005). The Finnish miracle of PISA: historical and sociological remarks on teaching and teacher education. Comparative Education, 41(4), 455-470.

Tweedie, Mrs A. (1897). Through Finland in carts. London: Thomas Nelson.

Välijärvi, J., Kupari, P., Linnakylä, Reinikainen, P., Sulkunen, S., Törnroos, J., \& Arffman, I. (2003). The Finnish success in PISA - and some reasons behind it 2: PISA 2003. OECD, PISA. Jyväskylä: University of Jyväskylä. Retrieved from https://ktl.jyu.fi/julkaisut/julkaisuluettelo/julkaisut/2007/d084

World Audit.org. (2015). Retrieved from http://www.worldaudit.org/corruption.htm

Yale Environmental Performance Index. (2016). Global metrics for the environment. Retrieved from https://issuu.com/2016yaleepi/docs/epi2016 final .

YLE Uutiset. (2016). More funding to prepare teachers for a "digital leap". Retrieved from http://yle.fi/uutiset/more funding to prepare teachers for a digital leap/8813061

\section{INTERVIEWS/PERSONAL COMMUNICATIONS}

Aalto, Mika. (2011). Principal, Oulun Lyseon Lukio. Pers. comm., 23 September.

Alameri, Raisa. (2011). Librarian, Sello Library, Leppävaara. Pers. comm., 9 September. Alatalo, Jukka. (2011). Principal, Kaakkuri School, Oulu. Pers. comm., 22 September. Frantsi, Hannele. (2011). Principal, Ymmersta School, Espoo. Pers. comm., 6 September. Fredrikson, Kaija. (2011). Educational Librarian, Helsinki City Library. Pers. comm., 7 September.

Hirvenoja, Anna-Liisa. (2011). Retired principal. Pers. comm., 23 September. Hurtig, Kimmo. (2011). Development Director, Tervaväylä School, Oulu. Pers. comm., 29 September. Itäpuro, Päivi. (2011). eVarikko, Tampere Department of Education. Pers. comm., 16 September.

Kallio, Marja. (2011). Principal, Myllyoja School, Oulu. Pers. comm., 27 September. Kallio, Marja. (2016). Principal, Myllyoja School, Oulu. Pers. comm., 11 May. Kannio, Lea. (2011). Media Centre, Helsinki Department of Education. Pers. comm., 7 September.

Kauppila, Elina. (2016). Information specialist, Oulun kaupunginkirjasto-maakuntakirjasto. Pers. comm., 11 May.

Kielinen, Professor Marko. (2011). Dean of Special Education, University of Oulu. Pers. comm., 19 September.

Korkeamäki, Professor Riitta-Liisa. (2011). Dean of Education, University of Oulu. Pers. comm., 19 September. Korkeamäki, Riku. (2011). University of Oulu. Pers. comm., 19 September. Kruuti, Leena. (2011). Deputy Head, Jyväskylä City Library. Pers. comm., 13 September. Kupari, Professor Pekka. (2011). FIER, University of Jyväskylä. Pers. comm., 12 September. 
Lauttaanaho, Anne. (2011). School Librarian, Jyväskylä Teacher Training School. Pers. comm., 13 September.

Louhivuori, Kari. (2011). Principal, Kirkkojärvi School, Espoo. Pers. comm., 8 September. Mäki, Päivi. (2011). OPPIS, Oulu City Department of Education. Pers. comm., 26 September. Mäki, Päivi. (2016). Quality manager. OPPIS, Oulu City Department of Education. Pers. comm., 11 May.

Ollila, Minttu. (2011). Vice Principal, Ymmersta School. Pers. comm., 6 September.

Pasanen, Irma. (2011). Associate Director of Aalto University Library, Otaniemi Campus.

Pers. comm., 9 September.

Ruohomäki, Eija. (2011). OPPIS, Oulu City Department of Education. Pers. comm., 26

September.

Saarivirta, Dr Toni. (2011). Faculty of Education, University of Tampere. Pers. comm., 15

September.

Sahlberg, Dr Pasi. (2011). Director-General of CIMO, Ministry of Education \& Culture. Pers. comm., 7 September.

Sulkunen, Dr Sari. (2011). FIER, University of Jyväskylä. Pers. comm., 12 September. Valtakorpi, Helena. (2011). Librarian, OPPIS, Oulu City Department of Education. Pers. comm., 30 September.

Valtakorpi, Helena \& Haaga, Alexandra. (2016). Librarian, OPPIS, Oulu City Department of Education/ Library student. Pers. comm., 12 May.

Wigell-Ryynänen, Barbro. (2011). Counsellor for Cultural Affairs, Ministry of Education and Culture. Pers. comm., 3 October.

With particular thanks to the following:

Dr John Collier, Hannele Frantsi, Kaija Fredrikson, Anna-Liisa Hirvenoja, Päivi Itäpuro, Professor Riitta-Liisa Korkeamäki, Professor Pekka Kupari, Dr Päivi Mäki, Irma Pasanen, Lyly Rajala, Professor Eero Sormunen, St Andrew's Cathedral School and Helena Valtakorpi. 
APPENDIX 1:

PISA RESULTS in brief (Mean Scores)

\begin{tabular}{|c|c|c|c|}
\hline PISA & Reading Literacy & Scientific Literacy & Mathematical Literacy \\
\hline $\begin{array}{l}2000 \\
32 \text { countries }\end{array}$ & $\begin{array}{l}\text { 1. Finland } \\
\text { 2. Canada } \\
\text { 3. New Zealand } \\
\text { 4. Australia }\end{array}$ & $\begin{array}{l}\text { 1. Korea } \\
\text { 2. Japan } \\
\text { 3. Finland } \\
\text { 7. Australia }\end{array}$ & $\begin{array}{l}\text { 1. Japan } \\
\text { 2. Korea } \\
\text { 3. New Zealand } \\
\text { 4. Finland } \\
\text { 5. Australia }\end{array}$ \\
\hline $\begin{array}{l}2003 \\
41 \text { countries }\end{array}$ & $\begin{array}{l}\text { 1. Finland } \\
\text { 2. Korea } \\
\text { 3. Canada } \\
\text { 3. Australia }\end{array}$ & $\begin{array}{l}\text { 1. Finland } \\
\text { 2. Japan } \\
\text { 3. Hong Kong } \\
\text { 4. Korea } \\
\text { 5. Australia }\end{array}$ & $\begin{array}{l}\text { 1. Hong Kong } \\
\text { 2. Finland } \\
\text { 3. Korea } \\
\text { 6. Japan } \\
\text { 8. Australia }\end{array}$ \\
\hline $\begin{array}{l}2006 \\
57 \text { countries }\end{array}$ & $\begin{array}{l}\text { 1. Korea } \\
\text { 2. Finland } \\
\text { 3. Hong Kong } \\
\text { 7. Australia } \\
\text { 13. Japan }\end{array}$ & $\begin{array}{l}\text { 1. Finland } \\
\text { 2. Hong Kong } \\
\text { 3. Canada } \\
\text { 4. Japan } \\
\text { 4. Australia }\end{array}$ & $\begin{array}{l}\text { 1. Chinese Taipei } \\
\text { 2. Finland } \\
\text { 3. Hong Kong/Korea } \\
\text { 8. Japan } \\
\text { 10. Australia }\end{array}$ \\
\hline $\begin{array}{l}2009 \\
65 \text { countries }\end{array}$ & $\begin{array}{l}\text { 1. Shanghai, China } \\
\text { 2. Korea } \\
\text { 3. Finland } \\
\text { 8. Japan } \\
\text { 9. Australia }\end{array}$ & $\begin{array}{l}\text { 1. Shanghai, China } \\
\text { 2. Finland } \\
\text { 3. Hong Kong } \\
\text { 5. Japan } \\
\text { 10. Australia }\end{array}$ & $\begin{array}{l}\text { 1. Shanghai, China } \\
\text { 2. Singapore } \\
\text { 6. Finland } \\
\text { 9. Japan } \\
\text { 15. Australia }\end{array}$ \\
\hline $\begin{array}{l}2012 \\
65 \text { countries }\end{array}$ & $\begin{array}{l}\text { 1. Shanghai-China } \\
\text { 4. Japan } \\
\text { 6. Finland } \\
\text { 10. Australia }\end{array}$ & $\begin{array}{l}\text { 1. Shanghai-China } \\
\text { 4. Japan } \\
\text { 5. Finland } \\
\text { 14. Australia }\end{array}$ & $\begin{array}{l}\text { 1. Shanghai-China } \\
\text { 7. Japan } \\
\text { 12. Finland } \\
\text { 18. Australia }\end{array}$ \\
\hline
\end{tabular}




\section{APPENDIX 2:}

\section{PISA RESEARCH TRIP - AREAS OF INVESTIGATION}

Areas of research that were investigated include:

- Basic aspects of schooling: school day, teaching hours, pay scales, qualifications, school and class sizes, learning support, school choice

- Teaching and learning: quality, practice teaching, teaching methods, ICT integration, continuity, student view, literacy, writing, reading, science and mathematics, resources, collaboration, motivation, repeating a school year, thinking skills

- Library and inquiry: research skills, use of school and public libraries, collaboration, reading and research skills through libraries, library promotion

- Assessment: nature of assessment, assessment of school quality

- International/global education: comparing Finnish and IB curricula, mechanisms for global education

- Employment: employment process, HR (human resources) practices

- Professional development: accountability, access to professional development

- Teacher training

- School structure: autonomy, support staff, principal and vice-principal roles

- Curriculum: national, programming

- Student support: strategies, equality, behaviour management, student welfare

- Other aspects: hot lunches, sense of community, co-curricular delivery, values education, pre-school care, reading, teaching day, practical and special subjects, school communication, communication with parents, supervision. 


\section{APPENDIX 3:}

\section{PISA RESEARCH TRIP: SCHOOLS, UNIVERSITIES, GOVERNMENT ORGANISATIONS, MUNICIPAL DEPARTMENTS OF EDUCATION AND TEACHER TRAINING FACILITIES, SCHOOL \& PUBLIC LIBRARIES}

Four universities:

- Aalto University - Library

- University of Jyväskylä - Finnish Institute of Educational Research (FIER) \& Library

- University of Tampere - Faculty of Education \& Faculty of Information Studies

- University of Oulu - Faculty of Education

Fourteen schools:

- Ymmersta School, Espoo (Grades 1-6)

- Keinutie School, Kontula, Helsinki (Grades 1-6)

- Kirkkojärvi School, Espoo (Grades 1-9)

- Jyväskylän Normaalikoulu Ylä-aste = Jyväskylä Teacher Training School (Grades 79)

- Jyväskylän Normaalikoulu Ala-aste = Jyväskylä Teacher Training School (Grades 16)

- Tampereen Lyseon Lukio (Tampere Senior Academic High School) (Grades 10-12)

- Oulun Normaalikoulu = Oulu Teacher Training School (Grades 1-6)

- Sanginsuu School, village school of 37 pupils (Grades 1-6)

- Kaakkuri School, Oulu (Grades 1-9)

- Oulun Lyseon Lukio (Oulu Senior Academic High School) (Grades 10-12)

- Myllyoja School, Oulu (Grades 1-6)

- Ritaharju Multifunction House \& School, Oulu (Grades 1-9)

- Oulu International School (Grades 1-12)

- Tervaväylä School, Oulu (special education school) (Grades 1-9)

Two government organisations:

- CIMO - Centre for International Mobility \& Co-operation

- Ministry of Education \& Culture

Three municipal departments of education/Learning \& resource centres:

- Media Centre, Helsinki City Department of Education

- OPPIS, Oulu City Department of Education

- eVarikko, Tampere City Department of Education

Eight public libraries:

- Helsinki City Library

- Kirjasto 10

- Urban Office (city outpost of Helsinki Library - CVs, wifi, music chairs, etc)

- Entresse Library, Espoo

- Sello Library, Leppävaara

- Jyväskylä City Library

- Tampere City Library (Metso)

- Oulu City Library 


\section{BIOGRAPHICAL NOTE}

Elizabeth GREEF has worked for many years as a teacher and teacher librarian in state and independent schools, most recently as the Head of Library Services at St Andrew's Cathedral School in Sydney, Australia and also for some years as adjunct faculty

member of Charles Sturt University (Masters program in Teacher Librarianship); she has recently retired. She has lived in Europe, the Middle East, Africa and Australia. Her interests focus on school libraries, information literacy, reading, learning spaces, global education and motivation. She has served for four years as the IASL Vice President Advocacy and Promotion and previously as Regional Director for Oceania. 